\title{
RECENZJA KSIĄŻKI SERGIO M. CARBONE I LORENZO SCHIANO DI PEPE PT. CONFLITTI DI SOVRANITÀ E DI LEGGI NEI TRAFFICI MARITTIMI TRA DIRITTO INTERNAZIONALE E DIRITTO DELL'UNIONE EUROPEA, TORINO 2010
}

Recenzowana praca stanowi efekt współpracy dwóch profesorów z Wydziału Prawa Uniwersytetu w Genui - Sergio M. Carbone i Lorenzo Schiano di Pepe. Swoją wiedzę i doświadczenie prezentowane również na wykładach uniwersyteckich przekazują tym razem w formie książki będącej uzupełnieniem wykładów nie tylko z bardzo dobrze rozwiniętego, z racji położenia geograficznego miasta, w którym funkcjonuje ten uniwersytet, prawa morskiego, ale także z prawa unijnego i międzynarodowego.

* Doktor nauk prawnych, adiunkt w Katedrze Prawa Cywilnego Europejskiej Wyższej Szkoły Prawa i Administracji, pracownik Kancelarii Radców Prawnych s. c. dr K. Szuma, H. Zambrowicz-Rybarczyk w Poznaniu.

1 S. M. Carbone, L. Schiano di Pepe, Konflikty suwerenności i praw w obrocie morskim pomiędzy prawem międzynarodowym a prawem Unii Europejskiej, Turyn 2010. 
Problematyka transportu (obrotu, handlu) morskiego oraz relatywnie duża ilość konfliktów stosowania przepisów w tej mierze, a co za tym idzie tematyka suwerenności poszczególnych państw biorących udział w procesie transportu, w ostatnich dziesięcioleciach budzą dość duże zainteresowanie w praktyce. Nie bez znaczenia jest tu także aspekt teoretyczny, który podlega ciągłemu rozwojowi ze względu na pojawiające się nowe regulacje w tym obszarze. Fakt zaistnienia problemów w praktyce realizacji transportu morskiego spowodował potrzebę uregulowania prawnego. W kontekście światowego procesu globalizacji rejestruje się tendencję związaną z podnoszeniem specjalizacji aktów normatywnych regulujących kwestie bardzo specyficzne, mających jednocześnie rozwiązywać konflikty międzypaństwowe powstałe w wyniku, wydaje się na pierwszy rzut oka banalnego procesu, jakim jest transport morski.

W związku z postępującym rozwojem dziedziny transportu, w tym transportu morskiego, powstała siatka przepisów, które w dość znaczny sposób zmieniają dotychczasowy porządek prawny dotyczący transportu morskiego.

Autorzy recenzowanej pracy badają przede wszystkim krajowy porządek prawny (tj. włoski) oraz ten unijny. Ten układ krajowo-unijny został poddany następnie analizie w aspekcie norm prawa międzynarodowego. Zbadano wzajemne relacje i oddziaływanie jednych norm na drugie.

Książka wydana została w listopadzie 2010 r. nakładem turyńskiego wydawnictwa G. Giappichelli Editore. Liczy 194 strony i składa się z siedmiu rozdziałów.

Pierwszą część recenzowanej pracy stanowi swego rodzaju przedmowa Autorów, wprowadzenie do podjętej problematyki oraz wskazanie na jej doniosłość w dobie specjalizacji wszystkich dziedzin życia, a co za tym idzie rozszerzania się regulacji prawnej na coraz to nowe dziedziny oraz jej szczegółowości zakresu przedmiotowego.

Kolejną część publikacji stanowi rozdział poświęcony rozważaniom dotyczącym jednolitego modelu prawnego $\mathrm{w}$ dziedzinie transportu morskiego oraz efektu przyjęcia przez uczestników obrotu międzynarodowego takiego modelu. Autorzy zwracają szczególną uwagę na nie dające się zastąpić żadnym 
innym instrumentem, konwencje międzynarodowe rozwiązujące problemy transportu morskiego ${ }^{2}$.

Drugi rozdział dotyczy współuczestnictwa oraz współpracy państwa bandery, państwa nadbrzeżnego oraz państwa portu przeznaczenia w zarządzaniu żeglugą morską ${ }^{3}$.

Trzeci rozdział dotyczy organizacji transportu morskiego i regulacji tej tematyki w prawie międzynarodowym i unijnym. Autorzy wskazują, że przyjmując szereg dyrektyw i rozporządzeń, Unia Europejska w znacznej mierze przyczyniła się do podwyższenia standardów bezpieczeństwa w transporcie morskim ${ }^{4}$. Należy tu zwłaszcza wymienić pakiety ustaw Erika I i Erika II, uchwalone po awariach statków „Erika” i „Prestige”. Autorzy wskazują, że po katastrofie tankowca „Erika” w rezolucjach

2 Do najważniejszych umów międzynarodowych, do których odwołują się Autorzy należą: Międzynarodowa konwencja z dnia 2 listopada 1973 r. o zapobieganiu zanieczyszczaniu morza przez statki (MARPOL), Międzynarodowa konwencja z dnia 1 listopada 1974 r. o bezpieczeństwie życia na morzu (SOLAS) oraz Międzynarodowa konwencja z dnia 7 lipca 1978 o wymaganiach w zakresie wyszkolenia marynarzy, wydawania im świadectw oraz pełnienia wacht (STCW). Konwencja Narodów Zjednoczonych o prawie morza, sporządzona w Montego Bay dnia 10 grudnia 1982 r., Dz. U. z 2002 r. Nr 59, poz. 543.

3 Autorzy wskazują przede wszystkim na aspekt współpracy w zakresie tworzenia standardów dotyczących wymiany technologii. Wskazują, że państwa, bezpośrednio lub za pośrednictwem właściwych organizacji międzynarodowych popierają tworzenie powszechnie przyjmowanych standardów dotyczących przekazywania technologii morskiej. W procesie tym należy w szczególności uwzględniać państwa rozwijające się.

$4 \mathrm{Na}$ ich wydanie miały przede wszystkim wpływ postanowienia Tytułu V TWE, w szczególności art. 71 ust. 1 lit. c) oraz art. 80 ust. 2 (Traktat Lizboński: tytuł VI, w szczególności art. 91 ust. 1 lit c) \{„W celu wykonania artykułu 90 [tekst art. 90 - „Cele Traktatów, w odniesieniu do kwestii uregulowanych w niniejszym tytule, są realizowane w ramach wspólnej polityki transportowej"] i z uwzględnieniem specyficznych aspektów transportu, Parlament Europejski i Rada, stanowiąc zgodnie ze zwykłą procedurą ustawodawczą i po konsultacji z Komitetem Ekonomiczno-Społecznym i Komitetem Regionów, ustanawiają [...] środki pozwalające polepszyć bezpieczeństwo transportu [...]\} oraz art. 100 ust. 2 Traktatu o funkcjonowaniu Unii Europejskiej \{„Parlament Europejski i Rada, stanowiąc zgodnie ze zwykłą procedurą ustawodawczą, mogą ustanowić odpowiednie przepisy dotyczące transportu morskiego i lotniczego. Stanowią one po konsultacji z Komitetem Ekonomiczno-Społecznym i Komitetem Regionów"\}). 
z dnia 20 stycznia 2000 r. i z dnia 2 marca 2000 r. Parlament Europejski zaapelował do Komisji Europejskiej o przedstawienie konkretnych wniosków dotyczących poprawy bezpieczeństwa na morzu. Przedstawione następnie przez Komisję Europejską pakiety bezpieczeństwa na morzu Erika I i Erika II zyskały poparcie Parlamentu Europejskiego. Z kolei, jak wskazują Autorzy, po katastrofie tankowca „Prestige” w pobliżu wybrzeża Hiszpanii w 2002 r. Parlament Europejski zdecydował o powołaniu komisji tymczasowej do spraw zwiększenia bezpieczeństwa na morzu (MARE).

Czwarty rozdział książki dotyczy zasad komunikacji morskiej. Autorzy wskazują na zasadę spójności oraz zasadę jednolitości we wspólnej polityce Unii Europejskiej. Autorzy precyzują, że tę pierwszą zasadę należy rozumieć zarówno poprzez zgodne działanie na rzecz umacniania i rozwijania wzajemnej solidarności politycznej w dziedzinie obrotu morskiego, jak i poprzez powstrzymywanie się od wszelkich działań, które byłyby sprzeczne z interesami Unii lub mogłyby zaszkodzić jej skuteczności jako spójnej sile $\mathrm{w}$ stosunkach międzynarodowych. Z kolei zasada jednolitości, jak wskazują Autorzy, oznacza swobodny przepływ produktów między państwami członkowskimi zapewniony poprzez likwidację ceł i innych ograniczeń związanych z ochroną rynków narodowych, a także poprzez wprowadzenie wspólnych cen i ujednoliconych zasad konkurencji oraz przyjęcie wspólnych reguł w obrocie morskim z krajami trzecimi.

Z kolei rozdział piąty pracy dotyczy kwestii związanych $\mathrm{z}$ zasadami odpowiedzialności pozakontraktowej $\mathrm{w}$ dziedzinie handlu morskiego.

Kolejna część pracy - rozdział szósty - dzieli się na dwa podrozdziały. Rozdział ten dotyczy odpowiedzialności kontraktowej powiązanej z transportem rzeczy drogą morską i aspektów odpowiedzialności pracownika $\mathrm{w}$ ramach stosunku pracy funkcjonującego w dziedzinie obrotu morskiego. Pierwszy podrozdział dotyczy aspektu transportu morskiego rzeczy, drugi - problemów związanych ze specyfiką pracy w tym sektorze. Autorzy wskazują, że niezbędne jest zapewnienie załodze optymalnej ochrony na wypadek wystąpienia nieszczęśliwego zdarzenia. Podejmują temat ubezpieczeń w obrocie morskim. Nawiązując do 
podrozdziału pierwszego należy wskazać, że Autorzy odwołują się m.in. do problematyki podmiotów logistycznego łańcucha spedycji morskiej, miejsca pierwszego załadunku i związanego z tym transportu dowozowego do portu załadowczego. Podejmują też tematykę przeładunku w porcie załadowczym i przeładunku w porcie wyładowczym.

Ostatni rozdział dotyczy różnych instytucji prawa morskiego. Autorzy zwracają uwagę przede wszystkim na specyfikę i złożoność spedycji morskiej, na tzw. obsługę konosamentową towarów.

Podsumowując, należy wskazać, że Autorzy skoncentrowali się na węzłowych zagadnieniach handlu morskiego. Przedstawione rozważania są dość szczegółowe i uporządkowane. Autorzy zaprezentowali je dzięki szerokiemu wachlarzowi aktów normatywnych, powołując jednocześnie stanowisko doktryny ${ }^{5}$. Podjęty temat jest interesujący z praktycznego punktu widzenia, a niektóre refleksje dotyczące rozważań nad prawem unijnym i międzynarodowym $\mathrm{w}$ aspekcie handlu morskiego są ważne w aspekcie teoretycznoprawnym.

Niektóre z zagadnień podjętych w opracowaniu mają charakter ogólny i mogą stanowić podstawę do badań bardziej zaawansowanych, inne cechuje dość duży stopień szczegółowości. Omówione kwestie przedstawione są na szerokim tle normatywnym i doktrynalnym. Zaletą książki są liczne odwołania do literatury oraz orzecznictwa. Pozwala ona czytelnikowi na wyrobienie poglądu na temat handlu morskiego i problemów pojawiających się w tej dziedzinie. O walorach recenzowanej pracy stanowią głównie aktualność i ranga podjętej problematyki.

5 Wszystkich czytelników chcących pogłębić poruszoną problematykę na gruncie prawa włoskiego można odesłać do następujących opracowań: S. M. Carbone, Principio di effettività e diritto comunitario, Napoli 2009; G. Gaja, A. Adinolfi, Introduzione al diritto dell'Unione Europea, Bari 2010; S. M. Carbone, C. Tuo, Spazio giudiziario europeo, Digesto delle Discipline Pubblicistiche - Aggiornamento, Torino 2010, s. 1-21; S. M. Carbone, Golden share e fondi sovrani: lo Stato nelle imprese tra libertà comunitarie e diritto statale, Diritto del commercio internazionale, 2009, s. 503-546; S. M. Carbone, L'autonomia privata nei rapporti economici internazionali ed i suoi limiti, Rivista di diritto internazionale privato e processuale, 2007, s. 891-920. 
Z pełnym przekonaniem można ją zarekomendować wszystkim czytelnikom zainteresowanym problematyką znaczącego fragmentu problematyki prawa morskiego, jakim jest transport morski. Z racji podjętych przez Autorów problemów, książkę można polecić również praktykom i teoretykom zajmującym się problemami prawa unijnego i międzynarodowego. 